\title{
Gliovascular and cytokine interactions modulate brain endothelial barrier in vitro
}

\author{
Ganta V Chaitanya', Walter E Cromer ${ }^{2}$, Shannon R Wells', Merilyn H Jennings ${ }^{1}$, P Olivier Couraud ${ }^{4,5,6}$, \\ Ignacio A Romero ${ }^{7}$, Babette Weksler ${ }^{7}$, Anat Erdreich-Epstein ${ }^{9}$, J Michael Mathis ${ }^{2}$, Alireza Minagar ${ }^{3}$ and \\ J Steven Alexander ${ }^{1,8^{*}}$
}

\begin{abstract}
The glio-vascular unit (G-unit) plays a prominent role in maintaining homeostasis of the blood-brain barrier (BBB) and disturbances in cells forming this unit may seriously dysregulate BBB. The direct and indirect effects of cytokines on cellular components of the BBB are not yet unclear. The present study compares the effects of cytokines and cytokine-treated astrocytes on brain endothelial barrier. 3-dimensional transwell co-cultures of brain endothelium and related-barrier forming cells with astrocytes were used to investigate gliovascular barrier responses to cytokines during pathological stresses. Gliovascular barrier was measured using trans-endothelial electrical resistance (TEER), a sensitive index of in vitro barrier integrity. We found that neither TNF- $\alpha$, IL-1 $\beta$ or IFN- $\gamma$ directly reduced barrier in human or mouse brain endothelial cells or ECV-304 barrier (independent of cell viability/ metabolism), but found that astrocyte exposure to cytokines in co-culture significantly reduced endothelial (and ECV-304) barrier. These results indicate that the barrier established by human and mouse brain endothelial cells (and other cells) may respond positively to cytokines alone, but that during pathological conditions, cytokines dysregulate the barrier forming cells indirectly through astrocyte activation involving reorganization of junctions, matrix, focal adhesion or release of barrier modulating factors (e.g. oxidants, MMPs).
\end{abstract}

Keywords: TNF- $a$, IL-1 $\beta$, IFN- $\gamma$, Brain endothelium, Astrocytes, Co-culture, Mono-Culture

\section{Background}

The blood brain barrier (BBB) is a unique astrocytecapillary-endothelial complex which maintains CNS homeostatic fluid balance, and serves as a first line of defense protecting the brain and parenchyma against pathogens, as well as blood-borne leukocytes and hormones, neurotransmitters and pro-inflammatory cytokines and chemokines [1,2]. The loss of BBB structural integrity and function plays a central role in the pathogenesis of neuroinflammatory diseases like multiple sclerosis, Alzheimer's disease, meningitis, brain tumors, intracerebral hemorrhage and stroke [3-10]. Many reports in the literature indicate that loss of $\mathrm{BBB}$ in neuroinflammation represents a result of complex often continuous interactions between the $\mathrm{BBB}$ and immune

\footnotetext{
* Correspondence: jalexa@lsuhsc.edu

'Department of Molecular and Cellular Physiology, School of Graduate Studies, Louisiana State University Health Sciences Center-Shreveport, 1501 Kings Hwy, Shreveport, LA 71130, USA

Full list of author information is available at the end of the article
}

cells, adhesive determinants and inflammatory cytokines, all of which may be relevant targets for therapy [11-18]. While several studies have modeled interactions between astrocytes and brain endothelial cells, fewer studies have considered how this gliovascular unit might be dysregulated by the combined influences of metabolic stress and cytokine exposure.

Astrocytes are the most abundant glial cells in the CNS, playing crucial roles in cerebral ion homeostasis, neuro-transmitter regulation, structural and metabolic support of neuronal and endothelial cells and BBB maintenance [19-21]. Furthermore, astrocytes provide an important link between neuronal and vascular units in the glucose-lactate shuttle and in modulating $\mathrm{Ca}^{2+}$ responses [22-29]. Importantly, astrocytes have been shown to play divergent roles in various pathologic conditions [29-32]. For example, following ischemic strokes, astrocytes protect neurons [33-35] by secreting several neurotrophic factors like glial cell-line derived neurotrophic factor [36], neurotrophin-3 [37,38], transforming
Ciomed Central

(c) 2011 Chaitanya et al; licensee BioMed Central Ltd. This is an Open Access article distributed under the terms of the Creative Commons Attribution License (http://creativecommons.org/licenses/by/2.0), which permits unrestricted use, distribution, and reproduction in any medium, provided the original work is properly cited. 
growth factor- $\beta 1$ [39], and vascular endothelial growth factor [40]. Astrocytes can also secrete pro-inflammatory cytokines such as TNF- $\alpha$, IL- $1 \beta$, and IL- 6 which would be anticipated to aggravate inflammatory injury to ischemic tissues [41]. The roles played by astrocytes and astrocyte-derived factors in maintaining or injuring the post-ischemic BBB are complex, cell-specific and timedependent. Several reports have indicate that astrocytes co-cultured with endothelial cells or astrocyte-conditioned media improve endothelial barrier integrity, however the potential effects of astrocytes on the cerebral endothelial cells during CNS stress contributing to the pathological loss of BBB are not yet as well understood [20]. The mechanisms through which factors secreted by stressed astrocytes (e.g. in response to glucose, serum, or oxygen deprivation) dysregulate endothelial barrier during pathologies e.g. cerebral ischemia remains an area under intensive investigation [42].

Cytokines exert diverse and cell-specific effects on BBB integrity [43-46]. TNF- $\alpha$ and IFN- $\gamma$ are among the best studied cytokines which cause differing permeability responses in different cell systems [47]. For example, IFN- $\gamma$ was shown to increase permeability in human colonic epithelial cells (T84), microvascular endothelial cells, human umbilical vein endothelial cells and cholangiocytes, but decreased permeability in human lung epithelial cells (Calu-3). TNF- $\alpha$ increases permeability of bovine pulmonary artery endothelial (BPAEC) monolayers, human colonic adenocarcinoma (Caco-2), HT29/ B6 and cholangiocytes, but decreased solute permeability of uterine epithelial cells (UECs) [47]. Further, TNF- $\alpha$ can either increase or decrease solute exchange depending on the type of insult in porcine renal epithelial cells (LLC-PK1) $[48,49]$. These effects are mediated by diverse mechanisms involving actin reorganization, monolayer motility, NF- $\mathrm{k} \beta$ activation, apoptosis and reorganization of junctional proteins [49-54].

Apart from direct actions of cytokines, factors secreted by astrocytes may also disturb BBB [32,42]. For example, matrix metalloproteinases ('MMP') -9 (MMP-9) and -13 (MMP-13), derived in part from astrocytes may contribute to post-ischemic BBB dysregulation [55-57] and MMP-9 inhibition partially protects against ischemic stroke, decreasing infarct size and BBB breakdown. Conversely, Tang et al. have reported that MMP- $-9^{-/-}$mice exhibit a more pronounced BBB damage and edema than controls (in a collagenase model of hemorrhage) [58]. Many other mediators may be involved in mediating the deleterious effect of stressed astrocytes on BBB during pathological conditions.

In the present study we investigated the direct or indirect influence of cytokines (TNF- $\alpha$, IL- $1 \beta$ and IFN$\gamma$ ) on brain endothelium and astrocytes (individually or in synergy) on barrier during metabolic stresses using a
3-D in vitro $\mathrm{BBB}$ model with human, mouse brain endothelial cells, ECV-304 and astrocytes. The results of our current study indicate that under conditions of pathological stress, astrocytes indirectly modify endothelial barrier responses to cytokines, leading to strikingly different barrier conditions observed in the absence of astrocytes. The differential roles of astrocytes and cytokines in modulating brain endothelial barrier properties are also discussed.

\section{Materials and methods Reagents}

Mouse rTNF- $\alpha$, was purchased from Endogen (Woburn, MA) Thermo scientific (Rockford, IL), Mouse rIL-1 $\beta$ was purchased from Chemicon (Temecula, CA) or Endogen. Mouse rIFN- $\gamma$ was purchased from Endogen. Human rTNF- $\alpha$ and rIFN- $\gamma$ were purchased from Thermo-scientific. Human rIL-1 $\beta$ was purchased from Endogen. All other chemicals were purchased from Sigma (St. Louis, MO) unless specified.

\section{Cell culture}

Murine brain endothelial cells (bEnd.3) provided by Dr. Eugene Butcher (Stanford Univ.). Human fetal astrocytes (HFA) were provided by Dr. Danica Stanimirovic (Univ. of Ottawa). Both cell types were both cultured in DMEM supplemented with $10 \%$ fetal calf serum (Hyclone) and 1\% Penicillin-Streptomycin-Amphotericin (PSA) ('complete medium' referred as 10\% DMEM). Media were changed every $2^{\text {nd }}$ day. Human brain endothelial cell line (HBMEC-3) was kindly provided by Dr. Anat Erdreich-Epstein, (Children's Hospital of Los Angeles, California) and were cultured in RPMI with $10 \%$ FCS with $2 \mathrm{mM}$ sodium pyruvate and 1\% PSA. An additional human brain endothelial cell line (HCMECD3) was provided by Dr. P.O. Couraud, (Institut Cochin, Paris, France) [59,60]. HCMEC-D3 cells were cultured in rat tail collagen coated plates $(100 \mathrm{ug} / \mathrm{ml})$ in medium consisting of EBM2 supplemented with 5\% FCS, $1.4 \mathrm{uM}$ hydrocortisone, $10 \mathrm{mM}$ HEPES, $1 \mathrm{ng} / \mathrm{ml}$ bFGF and 1\% PSA. As an additional control, ECV-304, (ATCC, Manassas, VA) a bladder carcinoma with several endothelial-like properties was also used in this study [61]; (these cells were cultured as described for HBMEC-3.)

\section{In vitro barrier function studies}

Brain endothelium (and ECV-304) was cultured on the apical surface of $8.0 \mu \mathrm{m}$ PETP transwell inserts (Falcon) placed in a 24-well culture plates ('outer chamber'). The outer chamber contained $1 \mathrm{ml}$ of medium with $0.5 \mathrm{ml}$ media in the insert. To generate contact-independent co-cultures, the apical/inner surface of the insert was seeded with either human or mouse brain endothelial 
cells or ECV-304 cells; astrocytes were cultured in the basal/outer chamber.

To create a 'close-contact' co-culture system closely resembling the in vivo gliovascular unit, after human or mouse endothelial (HCMEC-D3 or bEnd-3) cells were cultured on the apical surface and astrocytes were cultured on the basal side of the insert. These cultures were established by allowing $100 \mu \mathrm{l}$ of astrocyte cell suspension (approximately 20,000 cells) to adhere to the basal surface for $1 \mathrm{hr}$ before seeding the apical surface of the insert with endothelial cells. Later, inserts with attached endothelial cells and astrocytes were transferred into the outer chamber.

\section{Trans-endothelial electrical resistance (TEER)}

Trans-endothelial electrical resistance was measured using an epithelial volt-ohmmeter (EVOM) (World precision instruments, Sarasota, FL). Cultures systems on inserts were exposed to treatments, and at time points, were transferred to the TEER chamber (using matching media conditions) and electrical resistance recorded $\left(\mathrm{ohms} / \mathrm{cm}^{2}\right.$, no $=$ ohms $\left./ 0.33^{2}\right)$.

\section{Brain endothelial barrier permeability}

Mouse brain endothelial cells (bEnd3) were grown in transwell inserts (apical side) and at confluence were treated with cytokines in both apical and basal sides. TEER was recorded at $24 \mathrm{~h}$ time intervals. At $3 \mathrm{~d}, 50 \mu \mathrm{l}$ of FICT-dextran $(120 \mathrm{kD})$ at a final concentration of 1 $\mathrm{mg} / \mathrm{ml}$ (in culture medium) was added to the apical side of the brain endothelium. At various time points from $30 \mathrm{~min}$ to $6 \mathrm{~h}, 100 \mu \mathrm{l}$ of medium from the basal chamber was used to measure the extravasated FITC-dextran to the basal side across the endothelium. Equal volume of media was supplemented to replace the volume of used medium. The experiment was terminated after $6 \mathrm{~h}$. All the readings were measured at constant 'gain' settings. The values obtained were plotted on graph pad and checked for significance.

\section{Cytokine treatments}

Murine brain endothelial cells and human astrocytes were treated with matching mouse or human TNF- $\alpha$ $(20 \mathrm{ng} / \mathrm{ml}), \mathrm{IL}-1 \beta(20 \mathrm{ng} / \mathrm{ml})$ and IFN- $\gamma(1000 \mathrm{U} / \mathrm{ml})$ respectively. Depending on the study, cytokines (at specified concentrations) were added either to the apical or basal surface surrounding the insert (in contact-dependent or contact-independent systems).

\section{MTT assay}

Brain endothelial cells were grown in 96-well plates. At confluence, human and mouse brain endothelium was incubated with matching TNF- $\alpha(20 \mathrm{ng} / \mathrm{ml}), \mathrm{IL}-1 \beta$
(20 $\mathrm{ng} / \mathrm{ml})$, IFN- $\gamma(1000 \mathrm{U} / \mathrm{ml})$ for $4 \mathrm{~d}$. At the end of incubation time period, cell energy metabolism was measured by washing cells $3 \mathrm{X}$, and extracting in $300 \mathrm{ul}$ of acetic acid/isopropanol. Absorbance of the acid/isopropanol-extracted products was then measured at $450 \mathrm{~nm}$.

\section{Statistics}

Graphpad-3 InStat ${ }^{\mathrm{TM}}$ software was used to perform statistical analyses. One way-ANOVA or repeated measures ANOVA each with Dunnett's' post-hoc test or Bonferroni post-test were used to determine statistical significance. Sigmaplot ${ }^{\mathrm{TM}}$ was used to generate plots. "p $<0.05$ was considered to be statistically significant, ${ }^{* * *} \mathrm{p}<0.01$ very significant, and ${ }^{* * * *} \mathrm{p}<0.001$ highly significant.

\section{Results}

1a. Effect of mouse cytokines (apical + basal exposure) on mouse brain endothelial barrier (mono-cultures)

\section{Control}

Under control (untreated) conditions, barrier gradually diminishes over 7 days to $47.8 \pm 1.2 \%$ of baseline. Control cultures' barrier at $0 \mathrm{~d}$ was $276.67 \pm 14.98 \mathrm{ohms} /$ $\mathrm{cm}^{2}$ and at $7 \mathrm{~d}$ was $140.17 \pm 3.97 \mathrm{ohms} / \mathrm{cm}^{2}$.

TNF- $\alpha$

There was a slight decrease in mouse brain endothelial barrier treated with TNF- $\alpha$ till day 7 . This reflects a cumulative treatment on both apical + basal sides. No difference was observed in the mouse brain endothelial barrier treated either apically or basally. At day 7 the barrier was still higher than controls $(81.72 \pm 1.6$ vs. $47.8 \pm 1.2 \%$ of baseline). TNF- $\alpha$ treated cultures barrier at $0 \mathrm{~d}=274.67 \pm 6.0 \mathrm{ohms} / \mathrm{cm}^{2}$ and at $7 \mathrm{~d}=224.17 \pm$ $1.5 \mathrm{ohms} / \mathrm{cm}^{2}$.

\section{IL-1 $\beta$}

A gradual decrease in mouse brain endothelial barrier was observed in cells treated with IL-1 $\beta$ through day 7 . However, at day 7 the barrier was still slightly higher than controls ( $60.3 \pm 2.2$ vs. $47.8 \pm 1.2 \%$ of baseline). At $0 \mathrm{~d}$, IL-1 $\beta$ treated cultures resistance was $269.83 \pm 3.83$ $\mathrm{ohms} / \mathrm{cm}^{2}$ and at $7 \mathrm{~d}=162.83 \pm 4.09 \mathrm{ohms} / \mathrm{cm}^{2}$. IFN- $\gamma$

We observed an increase in mouse brain endothelial barrier with IFN- $\gamma$ over the other 2 cytokines or controls at all time points. The maximal resistance of brain endothelium treated with IFN- $\gamma$ was reached at day 3 (133.5 $\pm 2.1 \%$ of baseline). The resistance decreased from day 3 , but remained still higher than untreated controls at day $7(96.0 \pm 2 \%$ vs. $47.8 \pm 1.2 \%)$ (Figure 1a). Resistance of cultures treated with IFN- $\gamma$ at $0 \mathrm{~d}=261.67$ $\pm 3.2 \mathrm{ohms} / \mathrm{cm}^{2}$ and at $7 \mathrm{~d}=251.33 \pm 6.7 \mathrm{ohms} / \mathrm{cm}^{2}$. The rank order of TEER in this experimental model was IFN- $\gamma>$ TNF- $\alpha>$ IL- $1 \beta>$ Con. Inset shows the mode of culture and treatment. 


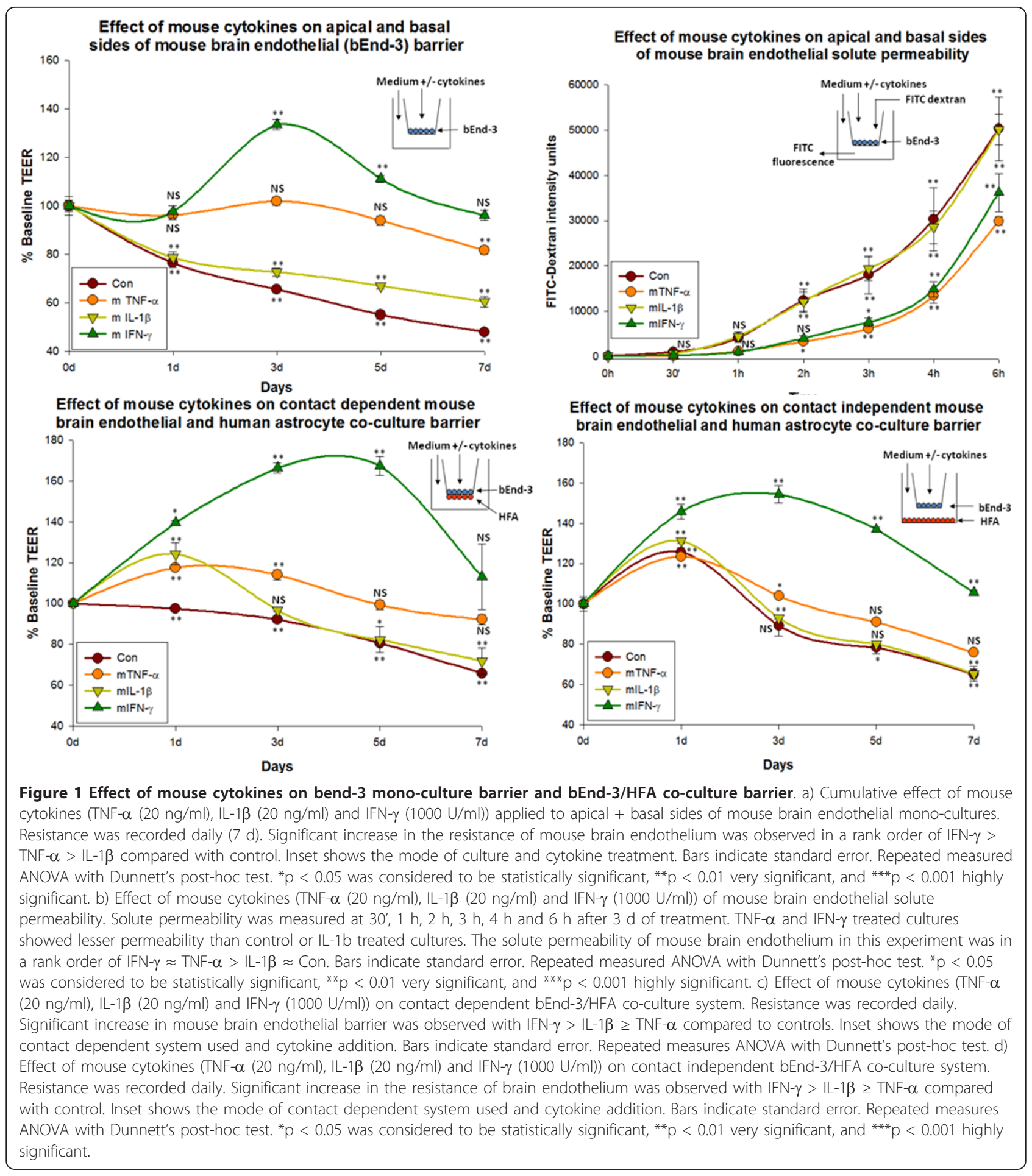

1b. Effect of mouse cytokines (apical and basal) on brain endothelial barrier (monoculture) solute permeability

Solute permeability measurements using FITC-dextran extravasation across endothelial barrier produced similar results correlating with our barrier integrity studies performed using EVOM meter. Since we observed a striking difference in TEER values between brain endothelium treated with cytokines at day3, $3 \mathrm{~d}$ time point was chosen to check the barrier solute permeability. While no difference between control and IL-1 $\beta$ treated brain endothelial FITC-dextran extravasation/permeability was observed, both TNF- $\alpha$ and IFN- $\gamma$ strikingly decreased solute 
permeability at all times starting from $30 \mathrm{~min}$ to $6 \mathrm{~h}$ compared to untreated controls (Figure 1b). This experiment accurately correlates the barrier integrity with solute permeability and helped to rely more the barrier integrity measurements in our further experiments using EVOM meter for longer time points.

\section{1c. Effect of mouse cytokines on endothelial + astrocyte co-culture barrier studies (Contact dependent co-cultures) Control}

Under untreated conditions, the TEER resistance of brain endothelial cells gradually decreased from day 1 $(106 \pm 0.5 \%$ to that of $\mathrm{t}=0$ (baseline)) through day 7 (to $65.9 \pm 1.4 \%$ of baseline). At day 0 the resistance of untreated co-cultures was $208.33 \pm 4.05 \mathrm{ohms} / \mathrm{cm}^{2}$ and at day7 resistance was $128.67 \pm 3.38 \mathrm{ohms} / \mathrm{cm}^{2}$.

TNF- $\alpha$

TNF- $\alpha$ significantly increased TEER of brain endothelium until day 3 , after which barrier decreased, (TEER values remained higher than control (Figure 1)). TEER peaked at day 3 (119 $\pm 1.4 \%$ of baseline). At day 7 the resistance of TNF- $\alpha$ treated brain endothelium remained higher than controls $(92.1 \pm 2.4$ vs. $65.9 \pm 1.4 \%)$. At day 0 the resistance of TNF- $\alpha$ treated co-cultures was $212.67 \pm 4.17 \mathrm{ohms} / \mathrm{cm}^{2}$ and at day 7 , resistance was $197.67 \pm 6.1 \mathrm{ohms} / \mathrm{cm}^{2}$.

IL-1 $\beta$

IL-1 $\beta$ also significantly increased TEER until day 2 , after which barrier gradually decreased. The resistance of IL$1 \beta$ treated cells was maximal at day $1(124.3 \pm 5.3 \%$ of baseline). At day 7 the resistance of IL-1 $\beta$ treated endothelium was only slightly higher than controls (71.9 \pm 6.5 vs. $65.9 \pm 1.4 \%)$. At day 0 , resistance of IL- $1 \beta$ treated co-cultures was $215.67 \pm 2.66 \mathrm{ohms} / \mathrm{cm}^{2}$ and at day7, resistance was $148.67 \pm 16.37 \mathrm{ohms} / \mathrm{cm}^{2}$.

IFN- $\gamma$

The fractional increase in the TEER of brain endothelium treated with IFN- $\gamma$ was greater than that of other 2 cytokines at all time points. The resistance of brain endothelium treated with IFN- $\gamma$ was maximal level at day 5 (167.2 $\pm 4.7 \%$ of baseline $)$. The resistance decreased from day 5, but remained higher than untreated brain endothelium (113 \pm 16 vs. $65.9 \pm 1.4 \%)$ (Figure 1c). At day 0 the resistance of IFN- $\gamma$ treated cocultures was $202 \pm 2.08 \mathrm{ohms} / \mathrm{cm}^{2}$ and at day7 resistance was $237.67 \pm 38.28 \mathrm{ohms} / \mathrm{cm}^{2}$. The rank order of TEER in this experimental model was IFN- $\gamma>$ TNF- $\alpha>$ IL$1 \beta>$ Con. Inset shows the mode of culture and treatment.

\section{1d Effect of mouse cytokine exposure on endothelial + astrocyte co-culture barrier studies (Contact independent co-culture) \\ Control}

Endothelial cells cultured with astrocytes in a contactindependent model showed a similar response to that of the cells in a contact-dependent model with minor exceptions. Control TEER significantly increased at day 1 , and was the time of maximal resistance (to $125.6 \pm$ $2.4 \%$ of that at baseline), differing with the resistance of cells in contact-dependent studies. The resistance gradually decreased till day 7 (to $65.1 \pm 2.6 \%$ of baseline TEER). At day 0 the resistance of untreated co-cultures was $188 \pm 7.2 \mathrm{ohms} / \mathrm{cm}^{2}$ and at day 7 , resistance was $124 \pm 3.5 \mathrm{ohms} / \mathrm{cm}^{2}$.

TNF- $\alpha$

TNF- $\alpha$ treated brain endothelium significantly increased TEER at day 1 which gradually decreased at later time points. TEER peaked at day $1(123.5 \pm 1.6 \%$ of baseline). At day 7, the resistance of TNF- $\alpha$ treated cells remained higher than that of untreated control endothelium $(75.87 \pm 0.4 \%$ vs. $65.1 \pm 2.6 \%)$. At day 0 the resistance of TNF- $\alpha$ treated co-cultures was 180.33 $\pm 8.37 \mathrm{ohms} / \mathrm{cm}^{2}$ and at day 7 , resistance was $161 \pm$ $10.0 \mathrm{ohms} / \mathrm{cm}^{2}$.

\section{IL-1 $\beta$}

IL-1 $\beta$ increased the resistance of brain endothelial cells at day 1 followed by a significant decrease in the resistance at day 7 . The resistance was maximal at day 1 $(131.2 \pm 1.1 \%$ of baseline $)$. The resistance of brain endothelial cells treated with IL-1 $\beta$ was similar to that of untreated brain endothelial cells at day 7 (65.32 \pm $3.7 \%$ vs. $65.15 \pm 2.6 \%$ ). At day 0 the resistance of IL- $1 \beta$ treated co-cultures is $156 \pm 8 \mathrm{ohms} / \mathrm{cm}^{2}$ and at day7 resistance is $125.33 \pm 0.8 \mathrm{ohms} / \mathrm{cm}^{2}$.

IFN- $\gamma$

IFN significantly increased the TEER of brain endothelial cells starting at day 1 through day 7 . The maximal resistance was observed at day $2(154.7 \pm 2.6 \%$ over baseline, data not shown). Interestingly, the resistance of brain endothelial cells treated with IFN $-\gamma$ remained higher than that of other cytokines or controls at day 7: $105.6 \pm 9 \%($ IFN $-\gamma)>75.87 \pm 0.4 \%($ TNF- $\alpha)>65.15 \pm$ $2.6 \%($ control $)=65.32 \pm 3.7 \%($ IL- $1 \beta)$ (Figure $1 \mathrm{~d})$. The rank order of TEER in this experimental model was IFN- $\gamma>$ TNF- $\alpha>$ IL- $1 \beta \approx$ Con. Inset shows the mode of culture and treatment. At day 0 the resistance of IFN- $\gamma$ treated co-cultures was $156.67 \pm 8.17 \mathrm{ohms} / \mathrm{cm}^{2}$ and at day 7 , resistance was $313.33 \pm 1.45 \mathrm{ohms} / \mathrm{cm}^{2}$.

\section{Figure 2. Effect of human cytokines on mouse brain} endothelium + human astrocyte co-culture barrier studies Treatment mode. Endothelial cells in the apical side (insert) were incubated in normal media, whereas astrocytes in the basal side were treated with media containing human cytokines.

\section{Control}

Endothelial cells co-cultured with astrocytes showed a progressive loss of TEER from days 3-7 (finally reaching $61.95 \pm 1.6 \%$ of initial baseline). At day 0 the resistance 
of untreated co-cultures was $188.33 \pm 0.8 \mathrm{ohms} / \mathrm{cm}^{2}$ and at day 7 , resistance was $116.67 \pm 3.1 \mathrm{ohms} / \mathrm{cm}^{2}$.

TNF- $\alpha$

We found that TNF- $\alpha$ treatment of astrocytes also decreased endothelial barrier resistance from days 3-7. Barrier resistance was almost similar to that of controls at day 7 , but was greater than controls $(71.51 \pm 1.9$ vs. $61.95 \pm 1.6 \%)$. At day 0 the resistance of TNF- $\alpha$ treated co-cultures is $176.67 \pm 1.4 \mathrm{ohms} / \mathrm{cm}^{2}$ and at day 7 , resistance was $126.33 \pm 3.4 \mathrm{ohms} / \mathrm{cm}^{2}$.

IL-1 $\beta$

When astrocytes were incubated in IL-1 $\beta$, we observed a progressive drop in barrier from days 3-7 days. Resistance in IL-1 $\beta$ treated co-cultures at day 7 was similar to that of controls $(63.51 \pm .8$ vs. $61.95 \pm 1.6 \%)$. At day 0 the resistance of IL- $1 \beta$ treated co-cultures was 172.67 $\pm 1.2 \mathrm{ohms} / \mathrm{cm}^{2}$ and at day 7 , resistance was $109.67 \pm$ $1.45 \mathrm{ohms} / \mathrm{cm}^{2}$.

IFN- $\gamma$

When astrocytes were incubated with human IFN- $\gamma$, a significant drop in barrier was observed over days 3-7. The resistance of IFN- $\gamma$ treated co-cultures at day 7 was lesser than that of controls $(46.47 \pm 5.4$ vs. 61.95 $\pm 1.6 \%$ ) (Figure 2). At day 0 the resistance of IFN- $\gamma$ treated co-cultures was $208 \pm 2.03 \mathrm{ohms} / \mathrm{cm}^{2}$ and at day 7 , resistance was $96.66 \pm 2.9 \mathrm{ohms} / \mathrm{cm}^{2}$. The rank

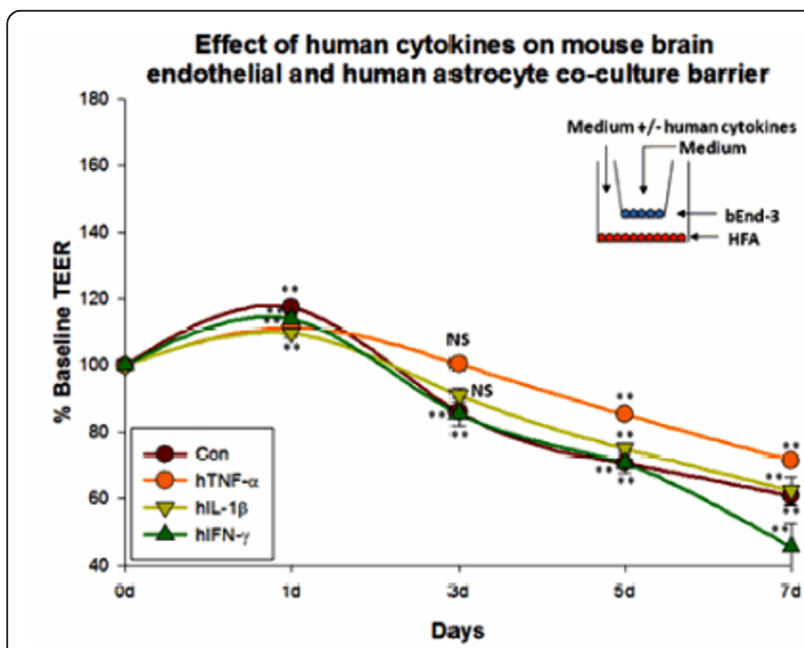

Figure 2 Effect of human cytokines on human astrocytes in contact-independent mouse brain endothelial co-culture barrier. Astrocytes were treated with human cytokines (TNF- $\alpha$ (20 $\mathrm{ng} / \mathrm{ml}), \mathrm{IL}-1 \beta(20 \mathrm{ng} / \mathrm{ml})$ and IFN- $\gamma(1000 \mathrm{U} / \mathrm{ml}))$ in a contact independent bEnd-3/HFA co-culture system. Resistance was recorded daily. hIFN- $\gamma$ treated co-cultures from $5 \mathrm{~d}-7 \mathrm{~d}$ showed decreased barrier compared to other treatment and control conditions. Inset shows the mode of co-culture system and cytokine addition. Bars indicate standard error. Repeated measures ANOVA with Dunnett's post-hoc test. ${ }^{*} p<0.05$ was considered to be statistically significant, ${ }^{* *} p<0.01$ very significant, and ${ }^{* * *} p<0.001$ highly significant. order of TEER in this experiment was TNF- $\alpha>\mathrm{IL}-$ $1 \beta \approx$ Con $>$ IFN $-\gamma$. These results show that cytokine effects, (IFN- $\gamma$ in particular) on brain endothelial barrier is cell-specific and depends on astrocyte vs. endothelial exposures.

\section{3) Effect of cytokines on mouse brain endothelial cell metabolism}

TNF- $\alpha$ at $4 \mathrm{~d}$ significantly decreased mouse brain endothelial metabolism ( $84.0 \pm 6.9 \%$ baseline). IL-1 $\beta$ also slightly decreased cell metabolism of mouse brain endothelium but did not reach statistical significance (97.37 $\pm 5.2 \%$ baseline). IFN- $\gamma$ showed a strong effect on mouse brain endothelial cells, decreasing metabolism more than the other 2 cytokines tested (reaching $51.5 \pm$ $4 \%$ baseline) (Figure 3 ).

To further confirm our previous experiments using more physiologically relevant models, 2 separate human brain endothelial lines (HBMEC-3 and HCMEC-D3) and ECV-304 (an endothelial-like bladder carcinoma cell line) were studied in monoculture, as well as in co-culture with human astrocytes and barrier integrity investigated.

4a. Effect of human cytokine exposure on apical + basal sides of human brain endothelial (HCMEC-D3) mono-

cultures

Control

Under untreated conditions, HCMEC-D3 barrier showed a progressive loss through day 7 (to $76.3 \pm 1.0 \%$ of baseline). At day 0 the resistance of untreated mono-cultures

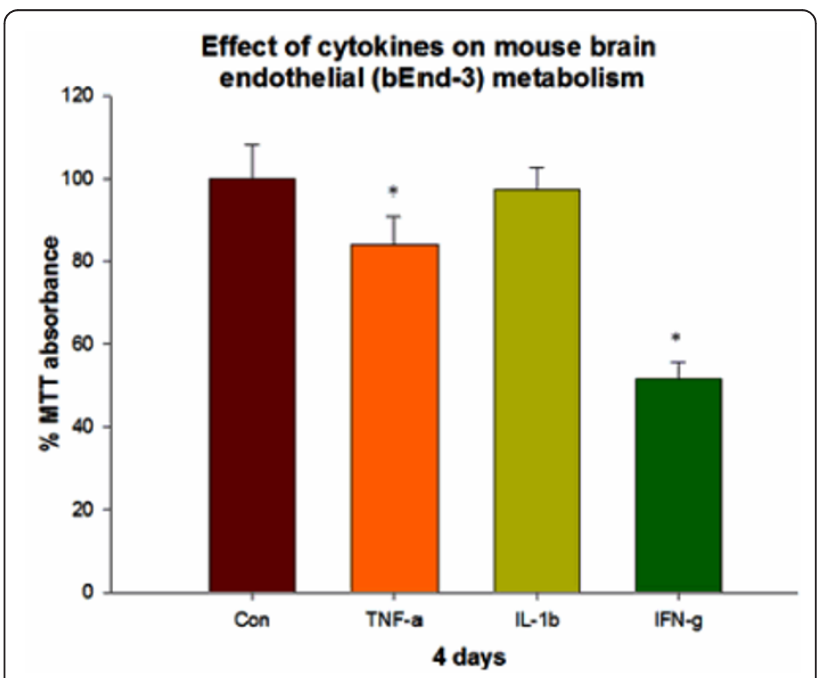

Figure 3 Effect of mouse cytokines (TNF- $\alpha$ (20 ng/ml), IL-1 $\beta$ (20 $\mathrm{ng} / \mathrm{ml})$ and IFN- $\gamma(1000 \mathrm{U} / \mathrm{ml}))$ on mouse brain endothelial metabolism. TNF- $\alpha(20 \mathrm{ng} / \mathrm{ml})$ and IFN- $\gamma(1000 \mathrm{U} / \mathrm{ml}))$ significantly decreased mouse brain endothelial cell metabolism by $4 \mathrm{~d}$ but not IL-1 $\beta(20 \mathrm{ng} / \mathrm{ml})$. 
was $297.33 \pm 5.04 \mathrm{ohms} / \mathrm{cm}^{2}$ and at day 7 , resistance was $233.33 \pm 2.66 \mathrm{ohms} / \mathrm{cm}^{2}$.

\section{TNF- $\alpha$}

A prominent decrease in HCMEC-D3 barrier treated with TNF- $\alpha$ was observed. At day 7 the barrier integrity was considerably lower than that of controls (50.13 \pm 0.6 vs. $76.3 \pm 1.0 \%$ of baseline). At day 0 the resistance of TNF- $\alpha$ treated cultures was $297.33 \pm 3.71 \mathrm{ohms} / \mathrm{cm}^{2}$ and at day 7 , resistance was $166 \pm 1.73 \mathrm{ohms} / \mathrm{cm}^{2}$.

IL-1 $\beta$

A gradual decrease in the HCMEC-D3 barrier treated with IL-1 $\beta$ was also observed until day 7 . However, the barrier of HCMEC-D3 treated with IL-1 $\beta$ was similar to that of controls. At day 7 the barrier of IL- $1 \beta$ treated HCMEC-D3 was same to that of controls $(73.07 \pm 0.3$ vs. $76.3 \pm 1.0 \%$ of baseline). At day 0 the resistance of IL- $1 \beta$ treated cultures was $298.67 \pm 1.73 \mathrm{ohms} / \mathrm{cm}^{2}$ and at day 7 , resistance was $226 \pm 1.0 \mathrm{ohms} / \mathrm{cm}^{2}$.

\section{IFN $\gamma$}

The percentage increase in IFN- $\gamma$ treated HCMEC-D3 was slightly greater than that of other 2 cytokines at all time points. The resistance of IFN- $\gamma$ treated cultures at day 7 was same as that of controls $(76.87 \pm 0.7$ vs. 76.3 $\pm 1.0 \%$ ) (Figure 4a). At day 0 the resistance of IFN- $\gamma$ treated cultures is $289.33 \pm 3.33 \mathrm{ohms} / \mathrm{cm}^{2}$ and at day 7 , resistance was $228.67 \pm 1.850 \mathrm{ohms} / \mathrm{cm}^{2}$. The rank order of TEER in this experimental model was IFN$\gamma>\mathrm{IL}-1 \beta \approx$ Con $>$ TNF$-\alpha$.

\section{4b. Effect of human cytokines on human brain endothelial (HCMEC-D3) and human astrocyte contact dependent co-culture barrier Control}

Under control conditions contact dependent HCMECD3/HFA co-cultures' (incubated in 10\% EBM2 in the apical side and 10\% DMEM in the basal side) barrier showed a progressive loss till $5 \mathrm{~d}$. At $5 \mathrm{~d}$ the barrier was $64.08 \pm 3.2 \%$. Resistance of contact dependent co-cultures' barrier at day 0 was $176.33 \pm 0.3$ and at 5 d resistance was $113 \pm 5.7 \mathrm{ohms} / \mathrm{cm}^{2}$ )

TNF- $\alpha$

TNF- $\alpha$ treated contact dependent co-culture barrier showed a striking loss in the barrier starting from $1 \mathrm{~d}$ till $5 \mathrm{~d}$. The barrier was $46.68 \pm 3.9 \%$ baseline. The resistance of TNF- $\alpha$ treated co-cultures barrier was $175.67 \pm 1.33 \mathrm{ohms} / \mathrm{cm}^{2}$ and at $5 \mathrm{~d}$ the resistance was $82 \pm 7.0 \mathrm{ohms} / \mathrm{cm}^{2}$.

IL-1 $\beta$

IL-1 $\beta$ treated co-cultures barrier was slightly lower but almost similar to that of control co-cultures barrier. At $5 \mathrm{~d}$ the barrier was $64.67 \pm 0.7 \%$ of baseline. The resistance values of IL-1 $\beta$ treated co-cultures at day 0 was $189.67 \pm 1.2 \mathrm{ohms} / \mathrm{cm}^{2}$ and at $5 \mathrm{~d}$ the resistance was $122.67 \pm 1.45 \mathrm{ohms} / \mathrm{cm} 2$
IFN- $\gamma$

IFN- $\gamma$ treated co-cultures barrier was lower compared to control co-cultures barrier. At $5 \mathrm{~d}$ the barrier was 57.58 $\pm 1.3 \%$ of baseline. Resistance of IFN- $\gamma$ treated co-cultures barrier at $0 \mathrm{~d}$ was $187 \pm 2.0 \mathrm{ohms} / \mathrm{cm}^{2}$ and at $5 \mathrm{~d}$ resistance was $107.6 \pm 2.6 \mathrm{ohms} / \mathrm{cm}^{2}$ (Figure $4 \mathrm{~b}$ ). The rank order of TEER in this experimental model was Con $\approx \mathrm{IL}-1 \beta>\mathrm{IFN}-\gamma>\mathrm{TNF}-\alpha$.

\section{4c. Effect of human cytokine exposure on human brain endothelial (HCMECD-3) and human astrocyte contact- independent co-culture barrier Control}

Under control conditions, HCMEC-D3/HFA contact independent co-cultures barrier showed a slight increase day 1 followed by a gradual decrease. At day 5 the barrier of the co-culture was (to $65.46 \pm 1.6 \%$ of baseline). At day 0 the resistance of untreated co-cultures was $164.33 \pm 1.45 \mathrm{ohms} / \mathrm{cm}^{2}$ and at day 5 , resistance was $119.67 \pm 2.1 \mathrm{ohms} / \mathrm{cm}^{2}$. The barrier was completely lost after $5 \mathrm{~d}$.

TNF- $\alpha$

A prominent decrease in HCMEC-D3/HFA co-culture barrier treated with TNF- $\alpha$ was observed. At day 5 the barrier integrity was considerably lower than that of controls ( $46.75 \pm 0.6$ vs. $65.46 \pm 1.6 \%$ of baseline). At day 0 the resistance of TNF- $\alpha$ treated co-cultures was $173.33 \pm 1.85 \mathrm{ohms} / \mathrm{cm}^{2}$ and at day 5 , resistance was $99.66 \pm 0.8 \mathrm{ohms} / \mathrm{cm}^{2}$. The barrier was completely lost after $5 \mathrm{~d}$.

IL-1 $\beta$

A gradual decrease in the HCMEC-D3/HFA co-culture barrier treated with IL-1 $\beta$ was also observed from day1 until day 5 . At day 5 the barrier of IL- $1 \beta$ treated HCMEC-D3 was slightly less than that of untreated cocultures $(56.08 \pm 1.3$ vs. $65.46 \pm 1.6 \%$ of baseline). At day 0 the resistance of IL- $1 \beta$ treated co-cultures was $169.33 \pm 3.1 \mathrm{ohms} / \mathrm{cm}^{2}$ and at day 5 , resistance was $110.33 \pm 1.76 \mathrm{ohms} / \mathrm{cm}^{2}$.

IFN- $\gamma$

A gradual decrease in the IFN- $\gamma$ treated HCMEC-D3/ HFA co-cultures was observed. The resistance of IFN- $\gamma$ treated cultures at day 5 is lesser than controls (53.37 \pm 1.0 vs. $65.46 \pm 1.6 \%$ ) (Figure 4c). At day 0 the resistance of IFN- $\gamma$ treated co-cultures is $168.67 \pm 3.3 \mathrm{ohms} / \mathrm{cm}^{2}$ and at day 5 , resistance is $106.33 \pm 1.45 \mathrm{ohms} / \mathrm{cm}^{2}$. The rank order of TEER in this experimental model was Con $>$ IL-1 $\beta \approx$ IFN $-\gamma>$ TNF- $\alpha$.

\section{4c. Effect of cytokines on human brain endothelium (HCMEC-D3) metabolism}

TNF- $\alpha$ at $3 \mathrm{~d}$ significantly decreased cell metabolism of HCMEC-D3 (76.49 $\pm 1.1 \%$ baseline control). IL-1 $\beta$ did not affect HCMEC-D3 cell metabolism (103.1 $\pm 1.1 \%$ 


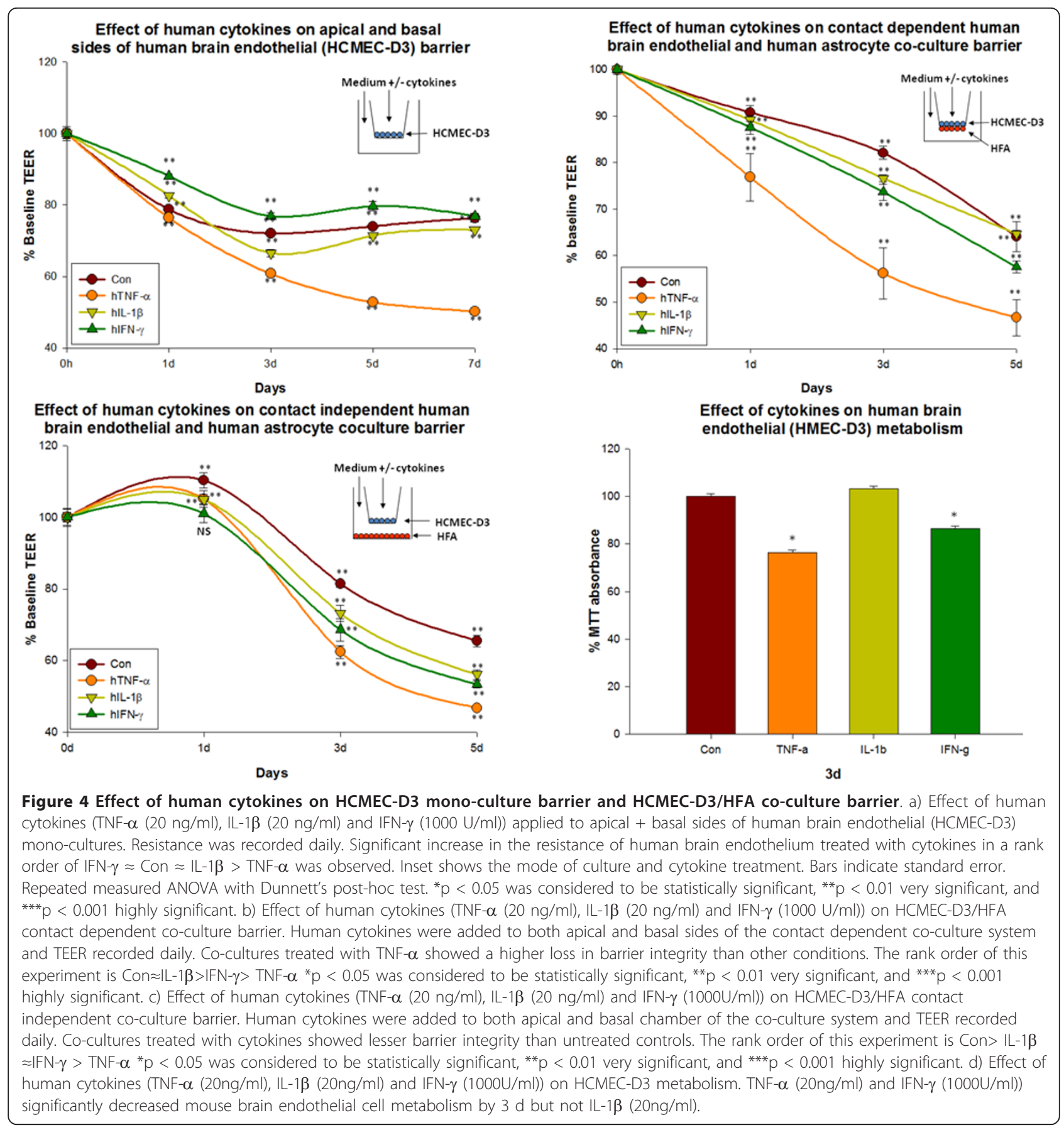

baseline control). IFN- $\gamma$ also significantly decreased HCMEC-D3 brain endothelial cell metabolism (86.57 \pm $0.9 \%$ baseline control) (Figure $4 \mathrm{~d}$ ).

5a. Effect of human cytokine exposure on apical + basal sides of human brain endothelial (HBMEC-3) monocultures

At confluence, HBMEC-3 cultures were treated with $10 \%$ RPMI with or without cytokines on both apical + basal sides. No significant effect of cytokines on HBMEC-3 barrier integrity was noted at any time point. The barrier integrity of cytokine treated cultures was similar to that of untreated cultures. However at day3 the barrier of the untreated cultures was slightly higher than that of other cytokine treated cultures. On day 5 barrier of the culture systems were the same (Con $(82.39 \pm 11.0 \%$ vs. baseline, resistance at $0 \mathrm{~d}=245.33 \pm$ 7.5 and at $5 \mathrm{~d}=205.33 \pm 2.85 \mathrm{ohms} / \mathrm{cm}^{2}$ ) vs. TNF- $\alpha$ 


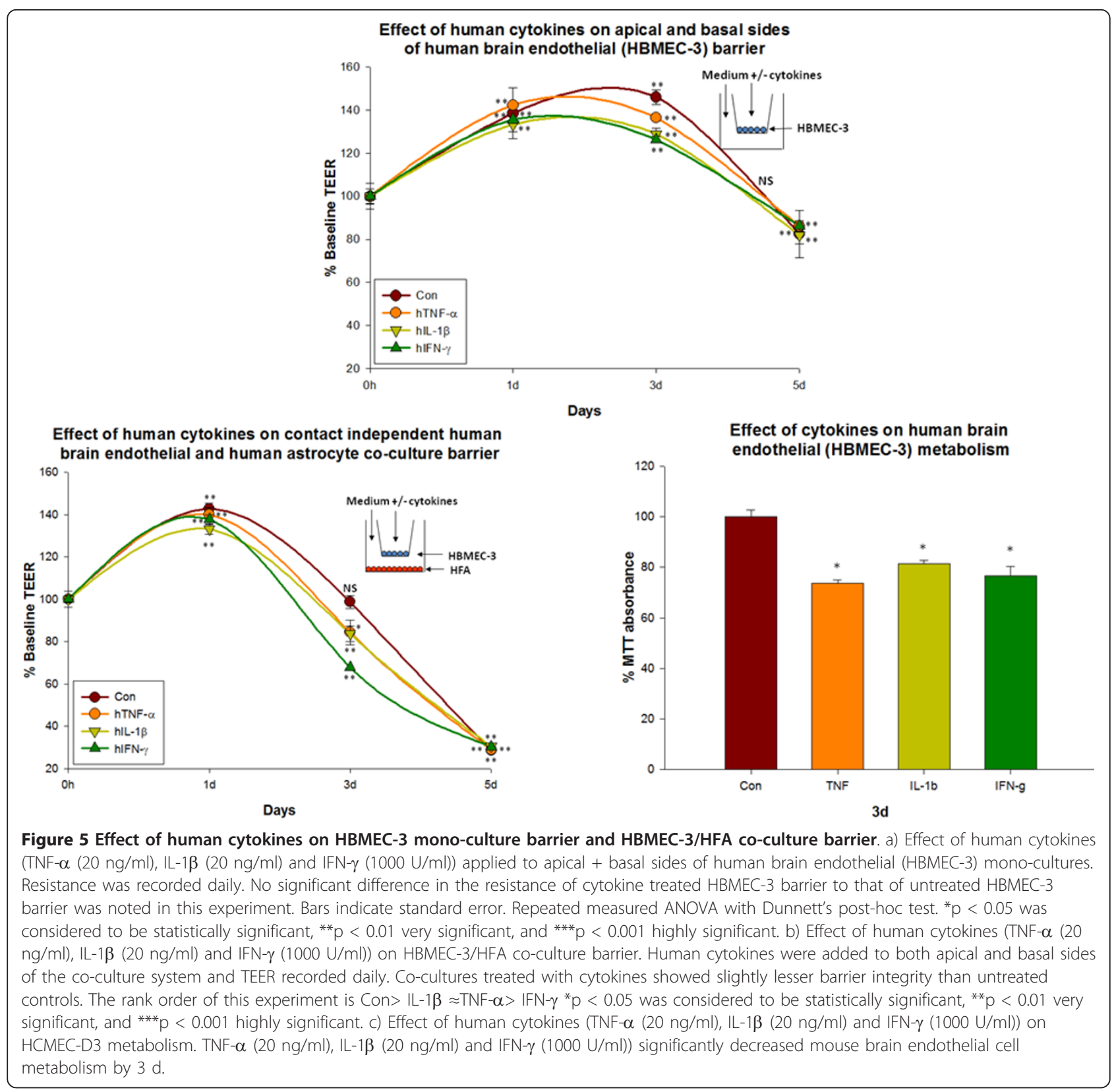

$(86.1 \pm 2.3 \%$, resistance at $0 \mathrm{~d}=270 \pm 7.6$ and at $5 \mathrm{~d}=$ $\left.234 \pm 5.5 \mathrm{ohms} / \mathrm{cm}^{2}\right)$ vs. IL- $1 \beta(81.87 \pm 4.0 \%$, resistance at $0 \mathrm{~d}=267 \pm 13.89$ and at $5 \mathrm{~d}=221.67 \pm 9.1 \mathrm{ohms} /$ $\left.\mathrm{cm}^{2}\right)$ vs. IFN- $\gamma(86.1 \pm 1.4 \%$, resistance at $0 \mathrm{~d}=260.67 \pm$ 7.5 and at $5 \mathrm{~d}=226 \pm 3.2 \mathrm{ohms} / \mathrm{cm}^{2}$ ) (Figure $5 \mathrm{a}$ ).

\section{5b. Effect of human cytokine exposure on human brain endothelial (HBMEC-3) and human astrocyte contact independent co-culture barrier \\ Control}

Under untreated conditions, HBMEC-3/HFA co-cultures barrier integrity was maintained until day 3 $(98.71 \pm 3.1 \%$ vs. baseline, resistance at $0 \mathrm{~d}=232.67 \pm$
8.8 and at $\left.3 \mathrm{~d}=229.67 \pm 7.3 \mathrm{ohms} / \mathrm{cm}^{2}\right)$. On day 5 the barrier in co-culture decreased dramatically $(28.65$ $\pm 0.2 \%$ of baseline, resistance at $5 \mathrm{~d}=66.67 \pm .6$ ohms $\left./ \mathrm{cm}^{2}\right)$.

TNF- $\alpha$

TNF- $\alpha$ treated HBMEC3/HFA co-culture's barrier was similar to that of untreated co-cultures at day 1 . However, by day 3 TNF- $\alpha$ treated co-culture barrier was reduced to less than that of controls $(84.3 \pm 5.8 \mathrm{vs}$. $98.71 \pm 3.1 \%$, resistance at $0 \mathrm{~d}=230.67 \pm 3.84,3 \mathrm{~d}=$ $\left.194.67 \pm 13.3 \mathrm{ohms} / \mathrm{cm}^{2}\right)$. By day 5 , barrier was similar to controls $(28.9 \pm 0.5$ vs. $28.65 \pm 0.2 \%$, resistance at $5 \mathrm{~d}$ $\left.=66.66 \pm 1.2 \mathrm{ohms} / \mathrm{cm}^{2}\right)$. 


\section{IL-1 $\beta$}

Barrier in IL-1 $\beta$ treated HBMEC-3/HFA co-cultures followed the same pattern as TNF- $\alpha$ treated co-cultures. At day 3, IL-1 $\beta$ treated co-culture barrier was lower than that of controls $(83.7 \pm 3.6$ vs. $98.71 \pm 3.1 \%$, resistance at $0 \mathrm{~d}=219.67 \pm 8.5$ and at $3 \mathrm{~d}=184 \pm 8 \mathrm{ohms} /$ $\mathrm{cm}^{2}$ ). At day 5 the barrier was dramatically reduced and was similar to that of controls $(30.5 \pm 0.2$ vs. $28.6 \pm$ $0.2 \%$, resistance at $5 \mathrm{~d}=67 \pm 0.57 \mathrm{ohms} / \mathrm{cm}^{2}$ ).

IFN- $\gamma$

No significant difference in the barrier of IFN- $\gamma$ treated HBMEC-3/HFA co-cultures was observed at day 1. However, on day3, IFN- $\gamma$ treated co-culture barrier was lower than controls and other cytokine treated HBMEC-3/HFA co-cultures $(67.7 \%$ vs. $98.71 \pm 3.1 \%$, resistance at $0 \mathrm{~d}=$ $215.67 \pm 3.4$ and at $\left.3 \mathrm{~d}=146 \mathrm{ohms} / \mathrm{cm}^{2}\right)$. At day5 the barrier was similar to controls (and other cytokine treated HBMEC-3/HFA co-cultures) (30.29 \pm 0.3 vs. $28.65 \pm 0.2 \%$, resistance at $5 \mathrm{~d}=65.33 \pm 0.6 \mathrm{ohms} / \mathrm{cm}^{2}$ ) (Figure $5 \mathrm{~b}$ ).

\section{5c. Effect of cytokines on HBMEC-3 metabolism}

TNF- $\alpha$, IL- $1 \beta$ and IFN- $\gamma$ significantly decreased HBMEC-3 brain endothelial metabolism by day3. While TNF- $\alpha$ decreased HBMEC-3 metabolism to $73.71 \pm$ $1.4 \%$ of control levels, IL-1 $\beta$ decreased HBMEC-3 metabolism to $81.44 \pm 1.4 \%$ and IFN- $\gamma$ to $76.64 \pm 3.6 \%$ of control levels (Figure 5c).

\section{6a. Effect of human cytokine exposure on apical + basal sides of ECV-304 mono-cultures Control}

Under control conditions, a progressive loss of barrier was observed in ECV-304 monolayers through day 7 (to $47.8 \pm 1.2 \%$ of baseline). At day 0 the resistance of untreated cultures was $353.67 \pm 3.33 \mathrm{ohms} / \mathrm{cm}^{2}$ and at day 7 , resistance was $181.33 \pm 2.9 \mathrm{ohms} / \mathrm{cm}^{2}$.

TNF- $\alpha$

A slight decrease in the ECV-304 barrier treated with TNF- $\alpha$ was observed until day 7 . However, at day 7 the barrier was still higher than controls $(81.72 \pm 1.6$ vs. $47.8 \pm 1.2 \%$ of baseline). At day 0 the resistance of TNF- $\alpha$ treated cultures is $367.67 \pm 3.5 \mathrm{ohms} / \mathrm{cm}^{2}$ and at day 7 , resistance is $287.33 \pm 12.7 \mathrm{ohms} / \mathrm{cm}^{2}$ ).

IL-1 $\beta$

A gradual decrease in the barrier formed by ECV-304 treated with IL-1 $\beta$ was also observed until day 7 . However, at day 7 the barrier was still slightly higher than controls $(60.3 \pm 2.2$ vs. $47.8 \pm 1.2 \%$ of baseline $)$. At day 0 the resistance of IL- $1 \beta$ treated cultures is $357.67 \pm 2.4 \mathrm{ohms} / \mathrm{cm}^{2}$ and at day 7 , resistance is $240 \pm 12.6 \mathrm{ohms} / \mathrm{cm}^{2}$ ).

IFN- $\gamma$

The fractional increase in ECV-304 barrier treated with IFN- $\gamma$ was greater than that of other 2 cytokines at all time points. The resistance of ECV-304 treated with
IFN- $\gamma$ was maximal level at day $3(133.5 \pm 2.1 \%$ of baseline, resistance at $0 \mathrm{~d}=366 \pm 2.08$ and at $3 \mathrm{~d}=415 \pm$ $13.2 \mathrm{ohms} / \mathrm{cm}^{2}$ ). The resistance decreased from day 3 , but still remained higher than that of untreated ECV304 at day $7(96.0 \pm 2$ vs. $47.8 \pm 1.2 \%$, resistance at $7 \mathrm{~d}$ $=260 \pm 9.07 \mathrm{ohms} / \mathrm{cm}^{2}$ ) (Figure 6a). The rank order of TEER in this experimental model was IFN- $\gamma>$ TNF- $\alpha>$ IL$1 \beta>$ Con.

\section{6b. Effect of human cytokine exposure on ECV-304 and human astrocyte contact independent co-culture barrier Control}

Compared to untreated ECV-304 mono-cultures, ECV304/HFA co-cultures lost the barrier more rapidly and were almost equal to baseline by $7 \mathrm{~d}$. The barrier at $5 \mathrm{~d}$ was $51.7 \pm 4.3 \%$ of baseline. At day 0 the resistance of untreated co-cultures was $327.67 \pm 13.2 \mathrm{ohms} / \mathrm{cm}^{2}$ and at day 5 , resistance was $169.67 \pm 14.1 \mathrm{ohms} / \mathrm{cm}^{2}$.

TNF- $\alpha$

ECV-304/HFA co-cultures treated with TNF- $\alpha$ also lost the barrier but remained higher than untreated co-cultures. At $5 \mathrm{~d}$ the barrier of TNF- $\alpha$ treated co-culture was lower than controls $(43.13 \pm 3.1$ vs. $51.7 \pm 4.3 \%$ of baseline). At day 0 the resistance of TNF- $\alpha$ treated cocultures is $327.67 \pm 3.8 \mathrm{ohms} / \mathrm{cm}^{2}$ and at day 5 , resistance is $141.33 \pm 10.3 \mathrm{ohms} / \mathrm{cm}^{2}$.

IL-1 $\beta$

A rapid decrease in the ECV-304/HFA co-culture barrier treated with IL-1 $\beta$ was also observed until $5 \mathrm{~d}$. At 5 $\mathrm{d}$ the barrier was still lower than controls $(33.73 \pm 3.3$ vs. $51.7 \pm 4.3 \%$ of baseline). At day 0 the resistance of IL-1 $\beta$ treated co-cultures is $335.67 \pm 12.33 \mathrm{ohms} / \mathrm{cm}^{2}$ and at day 5 , resistance is $112.67 \pm 11.26 \mathrm{ohms} / \mathrm{cm}^{2}$.

IFN- $\gamma$

IFN- $\gamma$ treated co-cultures lost the barrier in a similar fashion to IL- $1 \beta$ treatment. At $5 \mathrm{~d}$ the barrier of co-cultures treated with IFN- $\gamma$ was lesser than untreated cocultures $(32.73 \pm 0.3 \%$ vs. $51.7 \pm 4.3 \%$ of baseline $)$. At day 0 the resistance of IFN- $\gamma$ treated co-cultures is $311.67 \pm 4.9 \mathrm{ohms} / \mathrm{cm}^{2}$ and at day 5 , resistance is $102.67 \pm 1.0 \mathrm{ohms} / \mathrm{cm}^{2}$ (Figure $6 \mathrm{~b}$ ). The rank order of TEER in this experimental model was Con $>$ TNF- $\alpha>$ IL$1 \beta \approx$ IFN- $\gamma$. After $5 \mathrm{~d}$ both untreated and treated co-cultures' barrier was almost close to the baseline, indicating that more than the effect of cytokines, species matched stressed astrocytes can induce a more potent barrier permeability.

\section{6c. Effect of cytokines on ECV-304 metabolism}

All 3 cytokines in used in the study decreased ECV-304 metabolism. While TNF- $\alpha$ decreased ECV-304 metabolism to $83.13 \pm 2.5 \%$ to baseline control, IL-1 $\beta$ decreased ECV-304 metabolism to $90.26 \pm 2.5 \%$ and IFN- $\gamma$ to $72.8 \pm 1.7 \%$ (Figure $6 \mathrm{c}$ ). 


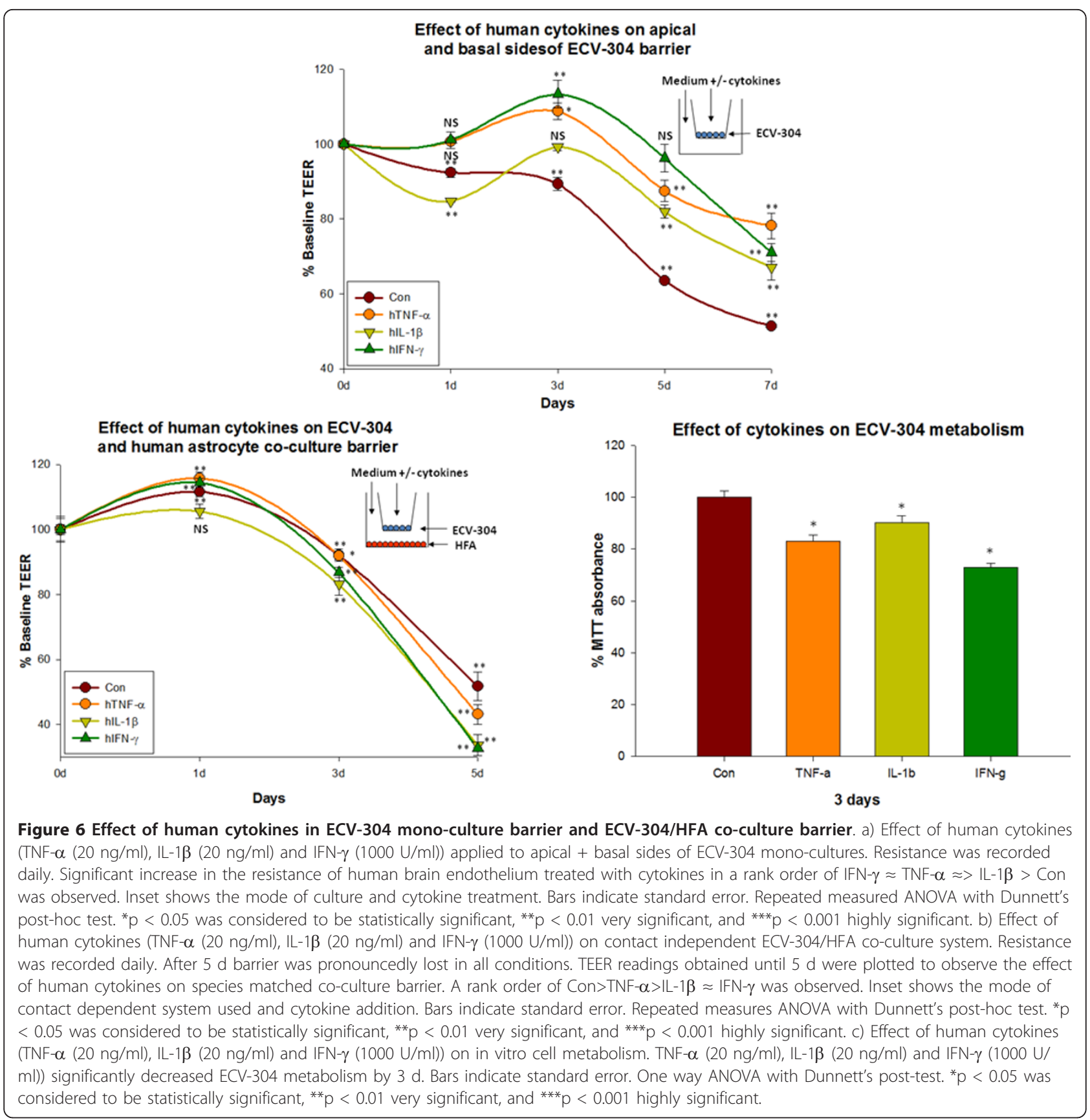

\section{Discussion}

The neurovascular unit is a highly organized functional complex composed of neurons, their associated glia and microvessels which match cerebral blood flow with metabolism [19,62-64]. This unit is further divided into gliovascular units in which astrocytes support the function of neurons and communicate with the associated microvasculature. Astrocytes play a central role in integrating this functional unit. These neuro- and gliovascular units sense changes in local metabolism and synchronize functions between the involved cell types during normal physiological regulation [62,65]. However, during pathological conditions the cumulative influences of several internal and external factors may significantly alter this balance, to compromise the normal BBB. Dysregulation of the $\mathrm{BBB}$ appears to be a critical step in the pathogenesis of many CNS disturbances. Severely compromised BBB function is observed in many clinical conditions including brain trauma, ischemic stroke, meningitis, glioma, Alzheimer's disease and multiple sclerosis [3-10]. Such disruptions in the BBB play a pivotal role in aggravating many forms of 
cerebrovascular pathology by intensifying inflammatory responses within the CNS environment [66].

IFN- $\gamma$ has been reported to decrease endothelial barrier [52,67-69], however it is worth noting that most of these studies have been performed in non-CNS endothelial cells. Brain endothelial cells differ from other endothelial cells in many respects including highly organized tight junctions which restrict paracellular transport and depend on biochemical support and interaction with astrocytes and neurons [70,71]. We attempted to identify specific responses involving interactions between astrocytes, individual cytokines, individually and in combination, to isolate possible mediators of barrier dysregulation in cell- and cytokine-mediated pathological conditions. Interestingly, our present study found unique brain endothelial responses to astrocytes and cytokines (compared to other endothelial types). Treatment with cytokines (i.e. TNF- $\alpha$, IFN- $\gamma$, IL- $1 \beta$ ) did not reduce barrier, compared to controls and paradoxically, TNF- $\alpha$ (on mouse brain endothelium) and IFN- $\gamma$ somewhat enhanced barrier in mono-culture conditions. The effect of these cytokines on brain endothelial barrier (also on ECV-304) persisted for 7 days. These results differ from some, (but not all) previous reports, and may reflect complex, cell- and species-specific interactions.

For instance, Wong et al., observed decreased electrical resistance in human $1^{\circ}$ endothelial cultures after treatment with $500 \mathrm{U} / \mathrm{ml}$ of IFN- $\gamma$ [69]. We also observed a similar decrease in barrier when astrocytes (but not endothelial cells or ECV-304 alone) were treated with IFN- $\gamma$ (in co-culture). Importantly, the observed barrier tightening effect of IFN- $\gamma$ was eliminated and reversed when astrocytes were treated with IFN- $\gamma$ in coculture. This clearly shows that factors released by astrocytes exposed to IFN- $\gamma$ (but perhaps not IFN- $\gamma$ directly on endothelial cells) may trigger endothelial signaling and barrier breakdown. This finding indicates that negative barrier effects of IFN- $\gamma$ on endothelial cells may be indirect, and reflect the production of factors produced by the astrocytes in our study. Stressed astrocytes may secrete several classes of factors, acting on brain endothelial cells (and other barrier forming cells, e.g. ECV-304) to compromise barrier. Activated astrocytes are known to release several factors like MMPs, that are involved in barrier breakdown [72-74]. Clear differences in the effect of cytokines on barrier are seen in different sets of conditions in the present study. For example, while some reports suggest that IL- $1 \beta$ dysregulates barrier [75], we found that barrier was maintained in brain endothelial monolayers treated with IL-1 $\beta$ (not different from controls). Moreover, when both astrocytes and brain endothelial cells were treated with cytokines in co-culture, trans-cellular resistance of co-cultures treated with TNF- $\alpha$ or IFN- $\gamma$ were lower than controls indicating that astrocyte stimulation is required for barrier dysregulation rather than cytokines alone. Similar results were also found for ECV-304 cells. IFN- $\gamma$ mediated barrier dysregulation involves a specific action on astrocytes rather than a direct effect on the brain endothelium (Figure 2, 4b, 5b and 6b). These results indicate that the specific actions of TNF- $\alpha$ in brain endothelial barrier dysregulation involves a synergy between endothelium, astrocytes and astrocyte-secreted factors and suggests that IFN- $\gamma$ indirectly dysregulates barrier/permeability through activation of astrocytes.

To determine if TEER changes might parallel changes in cell energy metabolism, mitochondrial respiration was measured in both human and mouse brain endothelium upon exposure to cytokines for 4 days using MTT. In normal medium, brain endothelial cells were metabolically active and TNF- $\alpha$ and IFN- $\gamma$ each significantly depressed metabolism of both mouse and human brain endothelial cells at days 3 and day 4 (significant change in metabolism vs. controls). These results indicate that the increase in barrier seen in human and mouse cells does not reflect metabolic depression. Moreover, it is possible that this decreased endothelial cell metabolism might be an adaptive response against cytokines which protects the barrier by conserving energy and preventing cell border contraction. This effect seems more prominent in IFN- $\gamma$ treated brain endothelium. Therefore, IFN- $\gamma$ may either modifies extracellular matrix (ECM) composition or alters endothelial junctions to prevent barrier dysregulation, a phenomenon which deserves further study [76]. Importantly, while some prior reports indicate that IFN- $\gamma$ injures cells during cerebral ischemia, recent reports also indicate that IFN- $\gamma$ protects neurons from CD8 $\mathrm{T}$ cell mediated injury [77-79]. Moreover, microglia treated with IFN- $\gamma$ and transplanted in vivo protect neurons by secreting neurotrophic factors [80]. In the same context, the observed beneficial barrier tightening effect of IFN- $\gamma$ may indicate another set of positive effects of IFN- $\gamma$ in BBB modulation.

The barrier of brain endothelial cells (and ECV-304) was elevated by IFN- $\gamma$ in all studies, except when astrocytes were treated with IFN- $\gamma$ in co-culture with endothelial cells (and ECV-304). These results indicate that cytokines (e.g. IFN- $\gamma$ ) may initiate different barrier responses depending on the types of cells contacted, acute vs. chronic timing, and the cytokine involved. Several studies have tried to determine mechanisms through which astrocytes modulate endothelial barrier using contact-dependent and independent co-culture models. Taking into consideration that intimate contact with astrocytes might alter endothelial barrier; we studied the effect of cytokines in a contact-dependent transwell system. Interestingly, our results were similar 
in both models, and might reflect species-specific differences. Porcine endothelial and rat glial cells have been shown to be a useful system for contact-dependent BBB studies [26]. Porcine and rat cells might thus be able initiate modulating signals despite species differences, which human and mouse co-cultures may not duplicate. Therefore, to match the species specificity both human brain endothelial monocultures (HCMEC-D3, HBMEC3) as well as ECV-304, and human brain endothelial: human astrocyte co-cultures (HCMEC-D3/HFA, HBMEC-3/HFA) and ECV-304/HFA) were prepared and evaluated for cytokine responses. Interestingly, similar responses were observed using mouse brain endothelial (bEnd-3) mono-cultures and mouse brain endothelial: human fetal astrocyte (bEnd-3/HFA) co-cultures. While TNF- $\alpha$ and IFN- $\gamma$ induced barrier in mono-cultures, cytokine treated co-cultures showed a rapid reduction in barrier. However, a pronounced decrease in mouse, human brain endothelium and ECV-304 barrier was observed when starved human astrocytes were used in species-matched co-cultures; barrier was severely decreased by $5 \mathrm{~d}$ compared to controls. This indicates that stressed astrocytes strongly promote barrier breakdown which may be further aggravated by elevated cytokine levels, rather than through direct effects of these cytokines on the endothelium.

Another important aspect of this study is the apparent resistance of endothelial cells to various stressful conditions. For example, although brain endothelium are quite resistant to external forces/factors, results with stressed astrocytes show that astrocytes can disturb endothelial barrier. During CNS disorders like ischemic stroke, stressed/activated astrocytes may increase production of cytokines/proteases and intensify other factors leading to $\mathrm{BBB}$ failure during $\mathrm{CNS}$ pathologies. Proinflammatory cytokines like TNF- $\alpha$, IL- $1 \alpha$, IL- $1 \beta$, IL-6, GM-GSF and chemokines like MCP-1 have been implicated in several forms of BBB breakdown $[11-15,17,18,66]$. Further, cytokine mediated chemokine modulation (e.g. IL-1 $\beta$ driven MCP-1) has also been implicated in BBB breakdown $[81,82]$. These results indicate that cytokines indirectly affect other barrier modulators. A consistent observation of this study is that astrocytes mediate cytokine mediated BBB breakdown. The pathophysiology of many CNS disorders such as cerebral ischemia, MS, glioma and brain trauma are closely associated with increased production of cytokines in the brain. The production of these resulting cytokines can strongly activate astrocytes to release factors that dysregulate BBB. Despite a paradoxical tightening of barrier in response to IFN- $\gamma$ and TNF- $\alpha$, the loss of barrier due to the effect of cytokines on astrocytes indicates that these coordinated cytokine-astrocyte interactions closely regulate pathological breakdown of the $\mathrm{BBB}$ and are model-specific.

\section{Conclusions}

Physiologically, astrocytes positively modulate brain endothelial barrier by stabilizing the solute barrier. Cytokines may exert detrimental effects on barrier in a differential and cell-specific model by astrocyte activation. Under appropriate pathological conditions activated astrocytes might dysregulate barrier biochemically by secreting factors that dysregulated or degrade BBB components. Interestingly, we found that astrocyte conditioned medium itself did improve barrier, and that cytokines either had no effect on, or increased barrier. Conversely, medium conditioned by astrocytes in the presence of these cytokines reduced barrier. Therefore cell-specific targets which neutralize effects of cytokines towards astrocytes or astrocyte-derived products towards endothelial cells may be beneficial in attenuating barrier dysregulation in several forms of neuroinflammation.

\section{Acknowledgements}

The authors acknowledge a post-doctoral fellowship support from the 'Feist Cardiovascular Research Endowment, LSUHSC-Shreveport for Dr. GVC and NIH DK43785 grant to Dr. Alexander JS.

\section{Author details}

'Department of Molecular and Cellular Physiology, School of Graduate Studies, Louisiana State University Health Sciences Center-Shreveport, 1501 Kings Hwy, Shreveport, LA 71130, USA. ${ }^{2}$ Cell Biology and Anatomy, School of Graduate Studies, Louisiana State University Health Sciences CenterShreveport, 1501 Kings Hwy, Shreveport, LA 71130, USA. ${ }^{3}$ Department of Neurology, School of Medicine, Louisiana State University Health Sciences Center-Shreveport, 1501 Kings Hwy, Shreveport, LA 71130, USA. ${ }^{4}$ Inserm, U1016, Institut Cochin, Paris, France. ${ }^{5}$ Cnrs, UMR8104, Paris, France. ${ }^{6}$ Univ Paris Descartes, Paris, France. ${ }^{7}$ Department of Biological Sciences, The Open University, Milton Keynes, UK. ${ }^{8}$ Department of Medicine, Weill Medical College, 1300 York Ave, New York, NY-10065, USA. 'Division of HematologyOncology, Departments of Pediatrics and Pathology, The Saban Research Institute at Children's Hospital Los Angeles and Keck School of Medicine, University of Southern California, 4650 Sunset Boulevard, Los Angeles, California 90027, USA.

\section{Authors' contributions}

GVC conceived and performed the majority of the experiments, analyzed data and wrote the study. WEC assisted in performing experiments and revising the manuscript. SW and $\mathrm{MJ}$ assisted with experiments and revisions. AEE provided HBMEC- 3 cells and helped in revisions of the study. POC, IAR, BW provided HCMEC-D3 cell lines and helped in revisions of the study. MJM assisted in interpretation and revision of the study. AM assisted in the interpretation and revision of the study. JSA helped conceive, analyze and interpret data and assisted in writing the manuscript. All authors read and approved the final manuscript.

\section{Authors' information}

Ganta Vijay Chaitanya, PhD, Department of Molecular and Cellular Physiology, Louisiana State University Health Sciences Center-Shreveport, Louisiana-71130

Walter Cromer, PhD, Department of Cell Biology and Anatomy, Louisiana State University Health Sciences Center- Shreveport, Louisiana-71130 
Shannon Wells, MPH, Department of Molecular and Cellular Physiology, Louisiana State University Health Sciences Center-Shreveport, Louisiana71130

Merilyn Jennings, BS, Department of Molecular and Cellular Physiology, Louisiana State University Health Sciences Center-Shreveport, Louisiana71130

Anat Erdreich-Epstein, MD, Division of Hematology-Oncology, Departments of Pediatrics and Pathology, The Saban Research Institute at Children's Hospital Los Angeles and the Keck School of Medicine, University of Southern California, 4650 Sunset Boulevard, Mailstop\#57, Los Angeles, California 90027.

P.O. Couraud, PhD, Department of Cell Biology, Université Paris Descartes, CNRS (UMR 8104), Paris, France, Inserm, U567,

Ignacio A. Romero, PhD, Department of Biological Sciences, The Open University, Milton Keynes, UK, Department of Medicine Babette Weksler, PhD, Weill Medical College, New York, NY USA.

J. Michael Mathis, PhD, Department of Cell Biology and Anatomy, Louisiana State University Health Sciences Center-Shreveport, Louisiana-71130 Alireza Minagar, MD’ Department of Neurology, Louisiana State University Health Sciences Center-Shreveport, Louisiana-71130,

J. Steven Alexander, PhD, Department of Molecular and Cellular Physiology, Louisiana State University Health Sciences Center-Shreveport, Louisiana71130

\section{Competing interests}

The authors declare that they have no competing interests.

Received: 10 May 2011 Accepted: 23 November 2011

Published: 23 November 2011

\section{References}

1. Stolp HB, Dziegielewska KM: Review: Role of developmental inflammation and blood-brain barrier dysfunction in neurodevelopmental and neurodegenerative diseases. Neuropathol Appl Neurobiol 2009, 35:132-146.

2. Weiss N, Miller F, Cazaubon S, Couraud PO: The blood-brain barrier in brain homeostasis and neurological diseases. Biochim Biophys Acta 2009, 1788:842-857.

3. Bell RD, Zlokovic BV: Neurovascular mechanisms and blood-brain barrier disorder in Alzheimer's disease. Acta Neuropathol 2009, 118:103-113.

4. del Zoppo GJ: Inflammation and the neurovascular unit in the setting of focal cerebral ischemia. Neuroscience 2009, 158:972-982.

5. Ivey NS, Maclean AG, Lackner AA: Acquired immunodeficiency syndrome and the blood-brain barrier. J Neurovirol 2009, 15:111-122.

6. Keep RF, Xiang J, Ennis SR, Andjelkovic A, Hua Y, Xi G, Hoff JT: Blood-brain barrier function in intracerebral hemorrhage. Acta Neurochir Suppl 2008, 105:73-77.

7. Lee J, Lund-Smith C, Borboa A, Gonzalez AM, Baird A, Eliceiri BP: Gliomainduced remodeling of the neurovascular unit. Brain Res 2009, 1288:125-134

8. Minagar A, Alexander JS: Blood-brain barrier disruption in multiple sclerosis. Mult Scler 2003, 9:540-549.

9. Minagar A, Jy W, Jimenez JJ, Alexander JS: Multiple sclerosis as a vascular disease. Neurol Res 2006, 28:230-235.

10. Simka M: Blood brain barrier compromise with endothelial inflammation may lead to autoimmune loss of myelin during multiple sclerosis. Curr Neurovasc Res 2009, 6:132-139.

11. Abbott NJ: Inflammatory mediators and modulation of blood-brain barrier permeability. Cell Mol Neurobiol 2000, 20:131-147.

12. Alvarez JI, Teale JM: Breakdown of the blood brain barrier and bloodcerebrospinal fluid barrier is associated with differential leukocyte migration in distinct compartments of the CNS during the course of murine NCC. J Neuroimmunol 2006, 173:45-55.

13. Banks WA, Erickson MA: The blood-brain barrier and immune function and dysfunction. Neurobiol Dis 2009.

14. Blamire AM, Anthony DC, Rajagopalan B, Sibson NR, Perry VH, Styles P: Interleukin-1beta -induced changes in blood-brain barrier permeability, apparent diffusion coefficient, and cerebral blood volume in the rat brain: a magnetic resonance study. J Neurosci 2000, 20:8153-8159.

15. Paul R, Koedel U, Winkler F, Kieseier BC, Fontana A, Kopf M, Hartung HP, Pfister HW: Lack of IL-6 augments inflammatory response but decreases vascular permeability in bacterial meningitis. Brain 2003, 126:1873-1882.
16. Suidan GL, Mcdole JR, Chen Y, Pirko I, Johnson AJ: Induction of blood brain barrier tight junction protein alterations by CD8 T cells. PLOS One 2008, 3:e3037.

17. Wilson CM, Gaber MW, Sabek OM, Zawaski JA, Merchant TE: Radiationinduced astrogliosis and blood-brain barrier damage can be abrogated using anti-TNF treatment. Int J Radiat Oncol Biol Phys 2009, 74:934-941.

18. Yang GY, Gong C, Qin Z, Liu XH, Lorris BA: Tumor necrosis factor alpha expression produces increased blood-brain barrier permeability following temporary focal cerebral ischemia in mice. Brain Res Mol Brain Res 1999, 69:135-143.

19. Abbott NJ: Astrocyte-endothelial interactions and blood-brain barrier permeability. J Anat 2002, 200:629-638.

20. Siddharthan V, Kim YV, Liu S, Kim KS: Human astrocytes/astrocyteconditioned medium and shear stress enhance the barrier properties of human brain microvascular endothelial cells. Brain Res 2007, 1147:39-50.

21. Willis CL, Nolan CC, Reith SN, Lister T, Prior MJ, Guerin CJ, Mavroudis G, Ray DE: Focal astrocyte loss is followed by microvascular damage, with subsequent repair of the blood-brain barrier in the apparent absence of direct astrocytic contact. Glia 2004, 45:325-337.

22. Bouzier-Sore AK, Serres S, Canioni P, Merle M: Lactate involvement in neuron-glia metabolic interaction: (13)C-NMR spectroscopy contribution. Biochimie 2003, 85:841-848

23. Chih CP, Roberts EL Jr: Energy substrates for neurons during neural activity: a critical review of the astrocyte-neuron lactate shuttle hypothesis. J Cereb Blood Flow Metab 2003, 23:1263-1281.

24. Jiang $M$, Chen $G$ : Ca2+ regulation of dynamin-independent endocytosis in cortical astrocytes. J Neurosci 2009, 29:8063-8074.

25. Magistretti PJ: Neuron-glia metabolic coupling and plasticity. J Exp Bio 2006, 209:2304-2311

26. Mangia S, Simpson IA, Vannucci SJ, Carruthers A: The in vivo neuron-to astrocyte lactate shuttle in human brain: evidence from modeling of measured lactate levels during visual stimulation. J Neurochem 2009, 109(Suppl 1):55-62.

27. Occhipinti R, Somersalo E, Calvetti D: Astrocytes as the glucose shunt for glutamatergic neurons at high activity: an in silico study. J Neurophysio/ 2009, 101:2528-2538.

28. Postnov DE, Koreshkov RN, Brazhe NA, Brazhe AR, Sosnovtseva OV: Dynamical patterns of calcium signaling in a functional model of neuron-astrocyte networks. J Biol Phys 2009.

29. Rossi D, Volterra A: Astrocytic dysfunction: Insights on the role in neurodegeneration. Brain Res Bull 2009.

30. Fischer S, Wobben M, Kleinstuck J, Renz D, Schaper W: Effect of astroglial cells on hypoxia-induced permeability in PBMEC cells. Am J Physiol Cell Physiol 2000, 279:C935-C944.

31. Gelot A, Villapol S, Billette d, Renolleau S, Charriaut-Marlangue C: Astrocytic demise in the developing rat and human brain after hypoxic-ischemic damage. Dev Neurosci 2009, 31:459-470.

32. Marchetti B: Cross-talk signals in the CNS: role of neurotrophic and hormonal factors, adhesion molecules and intercellular signaling agents in luteinizing hormone-releasing hormone (LHRH)-astroglial interactive network. Front Biosci 1997, 2:d88-125.

33. Ito $U$, Hakamata $Y$, Kawakami $E$, Oyanagi $K$ : Degeneration of astrocytic processes and their mitochondria in cerebral cortical regions peripheral to the cortical infarction: heterogeneity of their disintegration is closely associated with disseminated selective neuronal necrosis and maturation of injury. Stroke 2009, 40:2173-2181.

34. Takano T, Oberheim N, Cotrina ML, Nedergaard M: Astrocytes and ischemic injury. Stroke 2009, 40:58-12.

35. Trendelenburg G, Dirnagl U: Neuroprotective role of astrocytes in cerebral ischemia: focus on ischemic preconditioning. Glia 2005, 50:307-320.

36. Sandhu JK, Gardaneh M, Iwasiow R, Lanthier P, Gangaraju S, RibeccoLutkiewicz M, Tremblay R, Kiuchi K, Sikorska M: Astrocyte-secreted GDNF and glutathione antioxidant system protect neurons against 6OHDA cytotoxicity. Neurobiol Dis 2009, 33:405-414.

37. Lin CH, Cheng FC, Lu YZ, Chu LF, Wang CH, Hsueh CM: Protection of ischemic brain cells is dependent on astrocyte-derived growth factors and their receptors. Exp Neurol 2006, 201:225-233.

38. Rudge JS, Alderson RF, Pasnikowski E, McClain J, Ip NY, Lindsay RM: Expression of Ciliary Neurotrophic Factor and the Neurotrophins-Nerve Growth Factor, Brain-Derived Neurotrophic Factor and Neurotrophin 3-in Cultured Rat Hippocampal Astrocytes. Eur J Neurosci 1992, 4:459-471. 
39. Knuckey NW, Finch P, Palm DE, Primiano MJ, Johanson CE, Flanders KC, Thompson NL: Differential neuronal and astrocytic expression of transforming growth factor beta isoforms in rat hippocampus following transient forebrain ischemia. Brain Res Mol Brain Res 1996, 40:1-14.

40. Schmid-Brunclik N, Burgi-Taboada C, Antoniou X, Gassmann M, Ogunshola OO: Astrocyte responses to injury: VEGF simultaneously modulates cell death and proliferation. Am J Physiol Regul Integr Comp Physiol 2008, 295:R864-R873.

41. YU AC, Lau LT: Expression of interleukin-1 alpha, tumor necrosis factor alpha and interleukin- 6 genes in astrocytes under ischemic injury. Neurochem Int 2000, 36:369-377.

42. Haseloff RF, Blasig IE, Bauer HC, Bauer H: In search of the astrocytic factor (s) modulating blood-brain barrier functions in brain capillary endothelial cells in vitro. Cell Mol Neurobiol 2005, 25:25-39.

43. Carames B, Lopez-Armada MJ, Cillero-Pastor B, Lires-Dean M, Vaamonde C, Galdo F, Blanco FJ: Differential effects of tumor necrosis factor-alpha and interleukin-1 beta on cell death in human articular chondrocytes. Osteoarthritis Cartilage 2008, 16:715-722.

44. Dopp JM, kenzie-Graham A, Otero GC, Merrill JE: Differential expression, cytokine modulation, and specific functions of type-1 and type-2 tumor necrosis factor receptors in rat glia. J Neuroimmunol 1997, 75:104-112.

45. Ishihara K, Hirano T: Molecular basis of the cell specificity of cytokine action. Biochim Biophys Acta 2002, 1592:281-296.

46. Yu G, Fahnestock M: Differential expression of nerve growth factor transcripts in glia and neurons and their regulation by transforming growth factor-beta1. Brain Res Mol Brain Res 2002, 105:115-125.

47. Capaldo $C T$, Nusrat $A$ : Cytokine regulation of tight junctions. Biochim Biophys Acta 2009, 1788:864-871.

48. Marano CW, Laughlin KV, Russo LM, Peralta SA, Mullin JM: Long-term effects of tumor necrosis factor on LLC-PK1 transepithelial resistance. J Cell Physiol 1993, 157:519-527.

49. Peralta SA, Mullin JM, Knudsen KA, Marano CW: Tissue remodeling during tumor necrosis factor-induced apoptosis in LLC-PK1 renal epithelial cells. Am J Physiol 1996, 270:F869-F879.

50. Bogatcheva NV, Verin AD: The role of cytoskeleton in the regulation of vascular endothelial barrier function. Microvasc Res 2008, 76:202-207.

51. Brown RC, Mark KS, Egleton RD, Huber JD, Burroughs AR, Davis TP: Protection against hypoxia-induced increase in blood-brain barrier permeability: role of tight junction proteins and NFkappaB. J Cell Sci 2003, 116:693-700.

52. Oshima T, Laroux FS, Coe LL, Morise Z, Kawachi S, Bauer P, Grisham MB, Specian RD, Carter $P$, Jennings $S$, et al: Interferon-gamma and interleukin10 reciprocally regulate endothelial junction integrity and barrier function. Microvasc Res 2001, 61:130-143.

53. Petrache I, Verin AD, Crow MT, Birukova A, Liu F, Garcia JG: Differential effect of MLC kinase in TNF-alpha-induced endothelial cell apoptosis and barrier dysfunction. Am J Physiol Lung Cell Mol Physiol 2001, 280: L1168-L1178.

54. Polavarapu R, Gongora MC, Winkles JA, Yepes M: Tumor necrosis factorlike weak inducer of apoptosis increases the permeability of the neurovascular unit through nuclear factor-kappa B pathway activation. J Neurosci 2005, 25:10094-10100.

55. Lu DY, Yu WH, Yeh WL, Tang CH, Leung YM, Wong KL, Chen YF, Lai CH, Fu WM: Hypoxia-induced matrix metalloproteinase-13 expression in astrocytes enhances permeability of brain endothelial cells. J Cell Physiol 2009, 220:163-173

56. Tejima E, Zhao BQ, Tsuji K, Rosell A, van LK, Gonzalez RG, Montaner J, Wang $X$, LO EH: Astrocytic induction of matrix metalloproteinase-9 and edema in brain hemorrhage. J Cereb Blood Flow Metab 2007, 27:460-468

57. Yang Y, Estrada EY, Thompson JF, Liu W, Rosenberg GA: Matrix metalloproteinase-mediated disruption of tight junction proteins in cerebral vessels is reversed by synthetic matrix metalloproteinase inhibitor in focal ischemia in rat. J Cereb Blood Flow Metab 2007, 27:697-709.

58. Tang J, Liu J, Zhou C, Alexander JS, Nanda A, Granger DN, Zhang JH: Mmp9 deficiency enhances collagenase-induced intracerebral hemorrhage and brain injury in mutant mice. J Cereb Blood Flow Metab 2004, 24:1133-1145.

59. Cucullo L, Couraud PO, Weksler B, Romero IA, Hossain M, Rapp E, Janigro D: Immortalized human brain endothelial cells and flow-based vascular modeling: a marriage of convenience for rational neurovascular studies. J Cereb Blood Flow Metab 2008, 28:312-328.

60. Weksler BB, Subileau EA, Perriere N, Charneau P, Holloway K, Leveque M, Tricoire-Leignel H, Nicotra A, Bourdoulous S, Turowski P, et al: Blood-brain barrier-specific properties of a human adult brain endothelial cell line. FASEB J 2005, 19:1872-1874.

61. Suda K, Rothen-Rutishauser B, Gunthert M, Wunderli-Allenspach H: Phenotypic characterization of human umbilical vein endothelial (ECV304) and urinary carcinoma (T24) cells: endothelial versus epithelial features. In Vitro Cell Dev Biol Anim 2001, 37:505-514.

62. Abbott NJ, Ronnback L, Hansson E: Astrocyte-endothelial interactions at the blood-brain barrier. Nat Rev Neurosci 2006, 7:41-53.

63. Paulson OB, Hasselbalch SG, Rostrup E, Knudsen GM, Pelligrino D: Cerebral blood flow response to functional activation. I Cereb Blood Flow Metab 2009.

64. Takano T, Tian GF, Peng W, Lou N, Libionka W, Han X, Nedergaard M: Astrocyte-mediated control of cerebral blood flow. Nat Neurosci 2006, 9:260-267

65. Abbott NJ: Dynamics of CNS barriers: evolution, differentiation, and modulation. Cell Mol Neurobiol 2005, 25:5-23.

66. Stamatovic SM, Keep RF, Andjelkovic AV: Brain endothelial cell-cell junctions: how to "open" the blood brain barrier. Curr Neuropharmacol 2008, 6:179-192.

67. Huynh HK, Dorovini-Zis K: Effects of interferon-gamma on primary cultures of human brain microvessel endothelial cells. Am J Pathol 1993, 142:1265-1278.

68. Minagar A, Long A, Ma T, Jackson TH, Kelley RE, Ostanin DV, Sasaki M, Warren AC, Jawahar A, Cappell B, et al: Interferon (IFN)-beta 1a and IFNbeta $1 \mathrm{~b}$ block IFN-gamma-induced disintegration of endothelial junction integrity and barrier. Endothelium 2003, 10:299-307.

69. Wong D, Dorovini-Zis K, Vincent SR: Cytokines, nitric oxide, and cGMP modulate the permeability of an in vitro model of the human bloodbrain barrier. Exp Neurol 2004, 190:446-455.

70. Hawkins BT, Davis TP: The blood-brain barrier/neurovascular unit in health and disease. Pharmacol Rev 2005, 57:173-185.

71. Wolburg H, Lippoldt A: Tight junctions of the blood-brain barrier: development, composition and regulation. Vascul Pharmacol 2002, 38:323-337.

72. Lu DY, Yu WH, Yeh WL, Tang CH, Leung YM, Wong KL, Chen YF, Lai CH, Fu WM: Hypoxia-induced matrix metalloproteinase-13 expression in astrocytes enhances permeability of brain endothelial cells. J Cell Physiol 2009, 220:163-173

73. Tejima E, Zhao BQ, Tsuji K, Rosell A, van LK, Gonzalez RG, Montaner J, Wang $X$, Lo EH: Astrocytic induction of matrix metalloproteinase-9 and edema in brain hemorrhage. J Cereb Blood Flow Metab 2007, 27:460-468.

74. Yang Y, Estrada EY, Thompson JF, Liu W, Rosenberg GA: Matrix metalloproteinase-mediated disruption of tight junction proteins in cerebral vessels is reversed by synthetic matrix metalloproteinase inhibitor in focal ischemia in rat. $J$ Cereb Blood Flow Metab 2007, 27:697-709.

75. Argaw AT, Zhang Y, Snyder BJ, Zhao ML, Kopp N, Lee SC, Raine CS, Brosnan CF, John GR: IL-1 beta regulates blood-brain barrier permeability via reactivation of the hypoxia-angiogenesis program. J Immunol 2006, 177:5574-5584.

76. Alvarado J, del C Jr, Thomas LE: Modulation of membrane type 1 matrix metalloproteinase by LPS and gamma interferon bound to extracellular matrix in intestinal crypt cells. Cytokine 2008, 41:155-161.

77. Lambertsen KL, Gregersen R, Meldgaard M, Clausen BH, Heibol EK, Ladeby R, Knudsen J, Frandsen A, Owens T, Finsen B: A role for interferongamma in focal cerebral ischemia in mice. J Neuropathol Exp Neurol 2004, 63:942-955.

78. Liesz A, Suri-Payer E, Veltkamp C, Doerr H, Sommer C, Rivest S, Giese T, Veltkamp R: Regulatory T cells are key cerebroprotective immunomodulators in acute experimental stroke. Nat Med 2009, 15:192-199.

79. Richter K, Hausmann J, Staeheli P: Interferon-gamma prevents death of bystander neurons during CD8 T cell responses in the brain. Am J Pathol 2009, 174:1799-1807.

80. Imai F, Suzuki H, Oda J, Ninomiya T, Ono K, Sano H, Sawada M: Neuroprotective effect of exogenous microglia in global brain ischemia. J Cereb Blood Flow Metab 2007, 27:488-500. 
81. Anthony D, Dempster R, Fearn S, Clements J, Wells G, Perry VH, Walker K: CXC chemokines generate age-related increases in neutrophil-mediated brain inflammation and blood-brain barrier breakdown. Curr Biol 1998, 8:923-926.

82. Campbell SJ, Wilcockson DC, Butchart AG, Perry VH, Anthony DC: Altered chemokine expression in the spinal cord and brain contributes to differential interleukin-1beta-induced neutrophil recruitment. Neurochem 2002, 83:432-441.

doi:10.1186/1742-2094-8-162

Cite this article as: Chaitanya et al.: Gliovascular and cytokine interactions modulate brain endothelial barrier in vitro. Journal of Neuroinflammation 2011 8:162.

Submit your next manuscript to BioMed Central and take full advantage of:

- Convenient online submission

- Thorough peer review

- No space constraints or color figure charges

- Immediate publication on acceptance

- Inclusion in PubMed, CAS, Scopus and Google Scholar

- Research which is freely available for redistribution

Submit your manuscript at www.biomedcentral.com/submit
() Biomed Central 